Article

\title{
Exploring the Dedicated Knowledge Base of a Transformation towards a Sustainable Bioeconomy
}

\author{
Sophie Urmetzer ${ }^{1, *(\mathbb{D})}$, Michael P. Schlaile ${ }^{1,2}{ }^{\mathbb{C}}$, Kristina B. Bogner ${ }^{1}$, Matthias Mueller ${ }^{1}$ (i) and \\ Andreas Pyka ${ }^{1}$ \\ 1 Department of Innovation Economics (520i), University of Hohenheim, Wollgrasweg 23, \\ 70599 Stuttgart, Germany; schlaile@uni-hohenheim.de (M.P.S.); kristina.bogner@uni-hohenheim.de (K.B.B.); \\ m_mueller@uni-hohenheim.de (M.M.); a.pyka@uni-hohenheim.de (A.P.) \\ 2 Center for Applied Cultural Evolution, 1776 Millrace Drive, Eugene, OR 97403, USA \\ * Correspondence: sophie.urmetzer@uni-hohenheim.de; Tel.: +49-711-459-24482
}

Received: 16 April 2018; Accepted: 18 May 2018; Published: 23 May 2018

\begin{abstract}
The transformation towards a knowledge-based bioeconomy has the potential to serve as a contribution to a more sustainable future. Yet, until now, bioeconomy policies have been only insufficiently linked to concepts of sustainability transformations. This article aims to create such link by combining insights from innovation systems (IS) research and transformative sustainability science. For a knowledge-based bioeconomy to successfully contribute to sustainability transformations, the IS' focus must be broadened beyond techno-economic knowledge. We propose to also include systems knowledge, normative knowledge, and transformative knowledge in research and policy frameworks for a sustainable knowledge-based bioeconomy (SKBBE). An exploration of the characteristics of this extended, "dedicated" knowledge will eventually aid policymakers in formulating more informed transformation strategies.
\end{abstract}

Keywords: sustainable knowledge-based bioeconomy; innovation systems; sustainability transformations; dedicated innovation systems; economic knowledge; systems knowledge; normative knowledge; transformative knowledge; bioeconomy policy

\section{Introduction}

In the light of so-called wicked problems (e.g., [1,2]) underlying the global challenges that deeply affect social, environmental, and economic systems, fundamental transformations are required in all of these sustainability dimensions. Therefore, solution attempts need to be based on a systemic consideration of the dynamics, complementarities, and interrelatedness of the affected systems [3].

A relatively new and currently quite popular approach to sustainability transformations addressing at least some of these problems is the establishment of a bio-based economy: the bioeconomy concept relies on novel and future methods of intelligent and efficient utilization of biological resources, processes, and principles with the ultimate aim of substituting fossil resources (e.g., [4-11]). It is therefore frequently referred to as knowledge-based bioeconomy [11-13]. Whereas the idea of a bioeconomy is promoted both by academia and in policy circles, it remains unclear what exactly it is comprised of, how to spur the transformation towards a knowledge-based bioeconomy, and how it will affect sustainable development $[14,15]$. While the development and adoption of novel technologies that help to substitute fossil resources by re-growing biological ones certainly is a condition sine qua non, a purely technological substitution process will hardly be the means to confront the global challenges [3,16-20]. It must be kept in mind that a transformation towards a sustainable bioeconomy is only one important contribution to the overall transformation towards sustainability. We explicitly acknowledge that unsustainable forms of bio-based economies are conceivable and 
even-if left unattended-quite likely [21]. All the more, we see the necessity of finding ways to intervene in the already initiated transformation processes to afford their sustainability.

For successful interventions in the transformation towards a more sustainable bioeconomy, a systemic comprehension of the underlying dynamics is necessary. The innovation system (IS) perspective developed in the 1980s as a research concept and policy model [22-26] offers a suitable framework for such systemic comprehension. In the conventional understanding, according to Gregersen and Johnson, an IS "can be thought of as a system which creates and distributes knowledge, utilizes this knowledge by introducing it into the economy in the form of innovations, diffuses it and transforms it into something valuable, for example, international competitiveness and economic growth" ([27], p. 482). While welcoming the importance attributed to knowledge by Gregersen and Johnson and other IS researchers (e.g., [28-32]), particularly in the context of a knowledge-based bioeconomy, in this article, we aim to re-evaluate the role and characteristics of knowledge generated and exploited through IS. We argue that knowledge is not just utilized by and introduced in economic systems, but it also shapes (and is shaped by) societal and ecological systems more generally. Consequently, especially against the backdrop of the required transformation towards a sustainable knowledge-based bioeconomy (SKBBE), that which is considered as "something valuable" goes beyond an economic meaning (see also [33], on a related note). For this reason, it is obvious that the knowledge base for an SKBBE cannot be a purely techno-economic one. We rather see a need for exploring additional types of knowledge and their characteristics necessary for fostering the search for truly transformative innovation [16].

From the sustainability literature, we know that at least three types of knowledge are relevant for tackling (wicked) problems related to transformations towards sustainability: Systems knowledge, normative knowledge, and transformative knowledge [34-38]. Undoubtedly, these knowledge types need to be centrally considered and fostered for a transformation towards an SKBBE.

In the course of this paper, we aim to clarify the meaning and the characteristics of knowledge necessary for sustainability-oriented interventions in the transformation towards a bioeconomy. To reach this aim, we will explore the following research questions:

- Based on a combination of IS research with the sustainability science perspectives, what are the characteristics of knowledge that are instrumental for a transformation towards an SKBBE?

- What are the policy-relevant implications of this extended perspective on the characteristics of knowledge?

The article is structured as follows: Section 2 sets the scene by reviewing how knowledge has been conceptualized in economics. Aside from discussing in which way the understanding of the characteristics of economic knowledge has influenced innovation policy, we introduce the three types of knowledge (systems, normative, and transformative) relevant for governing sustainability transformations. Section 3 specifies the general meaning of these three types of knowledge, highlights their relevance and instrumental value for transformations towards an SKBBE, and relates them to the most prevalent characteristics of knowledge. Subsequently, Section 4 presents the policy-relevant implications that can be derived from our previous discussions. The concluding Section 5 summarizes our article and proposes some avenues for further research.

\section{Knowledge and Innovation Policy}

The understanding of knowledge and its characteristics varies between different disciplines. Following the Oxford Dictionaries, knowledge can be defined as "[f]acts, information, and skills acquired through experience or education" or simply as "theoretical or practical understanding of a subject" [39]. The Cambridge Dictionary defines knowledge as the "understanding of or information about a subject that you get by experience or study, either known by one person or by people generally" [40]. A more detailed definition by Zagzebski ([41], p. 92) states that "[k]nowledge is a highly valued state in which a person is in cognitive contact with reality. It is, therefore, a relation. 
On one side of the relation is a conscious subject, and on the other side is a portion of reality to which the knower is directly or indirectly related". Despite this multitude of understandings of knowledge, most researchers and policymakers probably agree with the statement that knowledge "is a crucial economic resource" ([28], p. 27). Therefore, the exact understanding and definition of knowledge and its characteristics strongly affect how researchers and policymakers tackle the question of how to best deal with and make use of this resource. Policymakers intervene in IS to improve the three key processes of knowledge creation, knowledge diffusion, and knowledge use (its transformation into something valuable). Policy recommendations derived from an incomplete understanding and representation of knowledge, however, will not be able to improve the processes of knowledge flow in IS and can even counteract the attempt to turn knowledge into something genuinely valuable.

\subsection{Towards a More Comprehensive Conceptualization of Knowledge}

A good example that highlights the importance of how we define knowledge is the understanding and treatment of knowledge in mainstream neoclassical economics. Neoclassical economists describe knowledge as an intangible good with public good features (non-excludable, non-rivalrous in consumption). Due to the (alleged) non-excludable nature of knowledge, new knowledge flows freely from one actor to another (spillover) such that other actors can benefit from new knowledge without investing in its creation (free-riding) [42]. In this situation, the knowledge-creating actors cannot fully benefit from the value they created, that is, the actors cannot appropriate the returns that resulted from their research activity (appropriability problem) [43]. There is no need for learning since knowledge instantly diffuses from one actor to another and the transfer of knowledge is costless. As Solow is often accredited with pointing out, knowledge falls "like manna from heaven" (see, e.g., [44,45] with reference to [46,47]), and it can instantly be acquired and used by all actors [48].

In contrast to mainstream neoclassical economics, (evolutionary or neo-Schumpeterian) innovation economists and management scholars consider other features of knowledge, thus, providing a much more appropriate analysis of knowledge creation and innovation processes. Innovation economists argue that knowledge can rather be seen as a latent public good [48] that exhibits many non-public good characteristics relevant for innovation processes in IS. Since these more realistic knowledge characteristics strongly influence knowledge flows, their consideration improves the understanding of the three key processes of knowledge creation, knowledge diffusion, and knowledge use (transforming knowledge into something valuable) [27]. In what follows, we present the latent public good characteristics of knowledge and structure them according to their relevance for these key processes in IS. Note that for the agents creating, diffusing, and using knowledge, we will use the term knowledge carrier in a similar sense as Dopfer and Potts ([49], p. 28), who wrote that "the micro unit in economic analysis is a knowledge carrier ... acquiring and applying knowledge".

Characteristics of knowledge that are most relevant in the knowledge creation process are the cumulative nature of knowledge (e.g., [50,51]), path dependency of knowledge (e.g., [52,53]), and knowledge relatedness (e.g., [54,55]). As the creation of new knowledge or innovation results from the (re-)combination of previously unconnected knowledge [56,57], knowledge has a cumulative character and can only be understood and created if actors already have a knowledge stock they can relate the new knowledge to [54,58]. The more complex and industry-specific knowledge gets, the higher the importance of prior knowledge and knowledge relatedness (see also the discussions in $[55,59])$.

Characteristics of knowledge that are especially important for the knowledge diffusion process are tacitness, stickiness, and dispersion. Knowledge is not equal to information [60,61]. In fact, as Morone [62] also explains, information can be regarded as that part of knowledge that can be easily partitioned and transmitted to someone else; information requires knowledge to become useful. Other parts of knowledge are tacit [63], that is, very difficult to be codified and to be transported [64]. Tacit knowledge is excludable and, therefore, not a public good [65]. So, even if the knowledge carrier is willing to share, tacitness makes it impossible sometimes to transfer this knowledge [66]. In addition, knowledge and 
its transfer can be sticky $[67,68]$, which means that the transfer of this knowledge requires significantly more effort than the transfer of other knowledge. According to Szulanski [67], both knowledge and the process of knowledge exchange can be sticky. The reasons may be the kind and amount of knowledge itself but also attributes of the knowledge carriers. Finally, the dispersion of knowledge also influences the possibility of diffusing knowledge. Galunic and Rodan [64] explain dispersed knowledge by using the example of a jigsaw puzzle. The authors state that knowledge is distributed if all actors receive a photocopy of the picture of the jigsaw puzzle. In contrast, knowledge is dispersed if every actor receives one piece of the jigsaw puzzle, meaning that everybody only holds pieces of the knowledge but not the 'whole' picture. Dispersed knowledge (or systems-embedded knowledge) is difficult to be transferred from one to the other actor (as detecting dispersed knowledge can be problematic, too [64]), thus hindering knowledge diffusion.

Characteristics of knowledge (and knowledge carriers) that influence the possibility to use the knowledge within an IS, that is, to transform it into something valuable, are the context specificity and local characteristics of knowledge. Even if knowledge is freely available in an IS, the public good features of knowledge are not necessarily decisive, and it might be of little or no use to the receiver. We have to keep in mind that knowledge itself has no value; it only becomes valuable to someone if the knowledge can be used, for example, to solve certain problems [69]. Assuming that knowledge has different values for different actors, more knowledge is not always better. Actors need the right knowledge in the right context at the right time and have to be able to combine this knowledge in the right way to utilize the knowledge. The "resource" knowledge might only be relevant and of use in the narrow context for and in which it was developed [64]. Moreover, to understand and use new knowledge, agents need absorptive capacities [70,71]. These capacities vary with the disparity of the actors exchanging knowledge: the larger the cognitive distance between them, the more difficult it is to exchange and internalize knowledge. Hence, the cognitive distance can be critical for learning and transforming knowledge into something valuable [72,73].

Note that while we have described the creation, diffusion, and use of knowledge in IS as rather distinct processes, this does not imply any linear character or temporal sequence of these processes. Quite the contrary, knowledge creation, diffusion, and use and the respective characteristics of knowledge may overlap and intertwine in a myriad of ways. For example, due to the experimental nature of innovation in general and the fundamental uncertainty involved, there are path dependencies, lock-ins (for example, in terms of stickiness), and feedback that lead to evolutionary cycles of variation/recombination, selection, and transmission or retention of knowledge. Moreover, the vast literature on knowledge mobilization, knowledge translation, and knowledge transfer (e.g., [74-77]) suggests that there can be various obstacles between the creation, diffusion, and use of knowledge, and that so-called knowledge mediators or knowledge brokers may be required to actively guide these interrelated processes (see also [78], on a related discussion). Consequently, we caution against reading the "trichotomy" of creation, diffusion, and use as connoting that knowledge will be put to good use by the carriers in the end so long as the conditions, such as social network structures, for diffusion are right. In fact, the notion of "optimal" network structures for diffusion may be misguided against the backdrop of the (in-)compatibility of knowledge, cognitive distance, and the dynamics underlying the formation of social networks [58].

\subsection{How Knowledge Concepts Have Inspired Innovation Policy Making}

Depending on the underlying concept of knowledge, different schools of thought influenced innovation policies in diverse ways (see also $[60,79,80]$ ). Following the mainstream neoclassical definition, the (alleged) public good characteristics of knowledge may result in market failure and the appropriability problem. As a consequence, policies have mainly focused on the mitigation of potential externalities and the elimination of inefficient market structures. This was done, for example, by incentive creation (via subsidies or intellectual property rights), the reduction of market entry barriers, and the production of knowledge by the public sector [81]. As Smith also states, "policies of 
block funding for universities, R\&D subsidies, tax credits for R\&D etc. [were] the main instruments of post-war science and technology policy in the OECD area" ([82], p. 8).

Policies changed (at least to a certain extent) when the understanding of knowledge changed. Considering knowledge as a latent public good, the main rationale for policy intervention is not market failure, but rather systemic problems $[81,83]$. Consequently, it can be argued that the mainstream neoclassical perspective neglects the importance (and difficulty) of facilitating knowledge creation, knowledge diffusion, and knowledge use in IS (see also [79,80], on a related note). Western innovation policies are often based on the IS approach and inspired by the more comprehensive understanding of knowledge and its implications for innovation. They generally aim at solving inefficiencies in the system (for example, infrastructural, transition, lock-in/path dependency, institutional, network, and capabilities failures as summarized by [83]). These inefficiencies are tackled, for example, by supporting the creation and development of different institutions in the IS as well as fostering networking and knowledge exchange among the system's actors [81]. Since "knowledge is created, distributed, and used in social systems as a result of complex sets of interactions and relations rather than by isolated individuals" ([84], p. 2), network science [85] especially has provided methodological support for policy interventions in innovation networks [86-88].

It is safe to state that innovation policies have changed towards a more realistic evaluation of innovation processes over the last decades [89], although in practice, they often still fail to adequately support processes of knowledge creation, diffusion, and use. Even though many policymakers nowadays appreciate the advanced understanding of knowledge and innovation, what Smith wrote more than two decades ago is arguably still valid to some extent, namely that "linear notions remain powerfully present in policy thinking, even in the new innovatory context" ([82], p. 8). Such a non-systemic way of thinking is also reflected by the strongly disciplinary modus operandi which is most obviously demonstrated by the remarkable difficulties still present in concerted actions at the level of political departments.

\subsection{Knowledge Concepts in Transformative Sustainability Science}

Policy adherence to the specific knowledge characteristics identified by economists has proven invaluable for supporting IS to produce innovations. However, to what end? So far, innovation has frequently been implicitly regarded as desirable per se $[3,90,91]$ and, by default, creating something valuable. However, if IS research shall be aimed at contributing to developing solution strategies to global sustainability challenges, a mere increase in innovative performance by improving the flow of economically relevant knowledge will not suffice [3]. In times of globally effective wicked problems challenging our current production and consumption patterns, it is evident that research into knowledge creation and innovation cannot be a task for economists or any other isolated discipline alone (see also [92], on a related discussion). Additional types of knowledge particularly relevant for addressing wicked problems have been proposed by sustainability science in general and transformational sustainability research in particular [36]. Solution options for the puzzle of reconciling economic development with sustainability goals have been found to require three kinds of knowledge: First, systems knowledge, which relates to the understanding of the dynamics and processes of ecological and social systems (including IS); second, normative knowledge, which determines the desired (target) states of a system; and third, transformative knowledge, which builds on systems and normative knowledge to inform the development of strategies for changing systems towards the desired state [34-38]. Although there are alternative terms for these three types of knowledge (such as explanatory knowledge, orientation knowledge, and action-guiding knowledge, as used in [93]), for the sake of terminological consistency with most recent publications, we adopt the terms systems knowledge, normative knowledge, and transformative knowledge.

The fundamental significance of these three kinds of knowledge (systems, normative, and transformative) for sustainability transformations has been put forward by a variety of research strands from theoretical $[34,35]$ to applied planning perspectives $[94,95]$. Explorations into the specific 
characteristics in terms of how such knowledge is created, diffused, and used within IS, however, are missing so far. For the particular case of a dedicated transformation towards an SKBBE, we seek to provide some clarification as a basis for an improved governance towards desired ends.

\section{Dedicated Knowledge for an SKBBE Transformation}

A dedicated transformation towards an SKBBE can be framed with the help of the newly introduced concept of dedicated innovation system (DIS) [3,16,96], which goes beyond the predominant focus on technological innovation and economic growth. DIS are dedicated to transformative innovation [97,98], which calls for experimentation and (co-)creation of solution strategies to overcome systemic inertia and the resistance of incumbents. In the following, we specify in what ways the IS knowledge needs to be complemented to turn into dedicated knowledge instrumental for a transformation towards an SKBBE. Such dedicated knowledge will thus have to comprise economically relevant knowledge as regarded in IS as well as systems knowledge, normative knowledge, and transformative knowledge. Since little is known regarding the meaning and the nature of the latter three knowledge types, we need to detail them and illuminate their central characteristics. This will help to fathom the processes of knowledge creation, diffusion, and use, which will be the basis for deriving policy-relevant implications in the subsequent Section 4.

\subsection{Systems Knowledge}

Once the complexity and interdependence of transformation processes on multiple scales is acknowledged, systemic boundaries become quite irrelevant. In the context of an SKBBE, systems knowledge must comprise more than the conventional understanding of IS in terms of actor configurations, institutions, and interrelations. As already stressed by Grunwald ([99], p. 154), "sufficient insight into natural and societal systems, as well as knowledge of the interactions between society and the natural environment, are necessary prerequisites for successful action in the direction of sustainable development". Although the IS literature has contributed much to systems knowledge about several levels of economic systems, including technological, sectoral, regional, national, and global IS, the interplay between IS, the Earth system (e.g., [100,101]), and other relevant (sub-)systems (e.g., [102-106]) must also be regarded as a vital part of systems knowledge in the context of sustainability and the bioeconomy. On that note, various authors have emphasized the importance of understanding systemic thresholds and tipping points (e.g., [107-110]) and network structures (e.g., [111,112]), which can thus be considered important elements of systems knowledge. In this regard, it may also be important to stress that systems knowledge is (and must be) subject to constant revision and change, because, as Boulding ([113], p. 9) already emphasized, "we are not simply acquiring knowledge about a static system which stays put, but acquiring knowledge about a whole dynamic process in which the acquisition of the knowledge itself is a part of the process".

To give a prominent example which suggests a lack of systems knowledge in bioeconomy policies, we may use the case of biofuels and their adverse effects on land-use and food supply in some of the least developed countries [114,115]. In this case, the wicked problem addressed was climate change due to excessive $\mathrm{CO}_{2}$ emissions, and the solution attempt was the introduction of bio-based fuel for carbon-reduced mobility. However, after the first boom of biofuel promotion, emissions savings were at best underwhelming or negative since the initial models calculating greenhouse gas savings had insufficiently considered the effects of the biofuel policies on markets and production: whereas the carbon intensity of biofuel crop cultivation was taken into account, the overall expansion of the agricultural area and the conversion of former grasslands and forests into agricultural land was not $[114,115]$. These indirect land-use change (ILUC) effects are estimated to render the positive effects of biofuel usage more than void, which represents a vivid example for how (a lack of) comprehensive systems knowledge can influence the (un)sustainability of bioeconomy transformations.

In accordance with much of the IS literature's focus on knowledge and the common intellectual history of IS and evolutionary economics (e.g., [23]), it becomes clear that an economic system, 
in general, and a (knowledge-based) bioeconomy, in particular, may also be regarded as "a coordinated system of distributed knowledge" ([69], p. 413). Potts posits that "[k]nowledge is the solution to problems. A solution will consist of a rule, which is a generative system of connected components" ([69], p. 418f.). The importance of rules is particularly emphasized by the so-called rule-based approach (RBA) to evolutionary economics developed by Dopfer and colleagues (e.g., [49,116-121]). According to the RBA, a "rule is defined as the idea that organizes actions or resources into operations. It is the element of knowledge in the knowledge-based economy and the locus of evolution in economic evolution" ([49], p. 6). As Blind and Pyka also elucidate, "a rule represents knowledge that enables its carrier to perform economic operations, i.e., production, consumption and transactions. The distinction between generic rules and operations based on these rules is essential for the RBA" ([122], p. 1086). According to the RBA, these generic rules may be further distinguished into subject and object rules: subject rules are the cognitive and behavioral rules of an economic agent, whereas object rules are social and technical rules that represent the organizing principles for social and technological systems [49,118]. The latter include, for example, Nelson-Winter organizational routines [123] and Ostrom social rules (e.g., [124-126]). From this brief summary of the RBA, it already becomes clear that an understanding of the bioeconomic systems' rules and their interrelations is an instrumental element of systems knowledge. Or, as Meadows puts it, "[p]ower over the rules is real power" ([127], p. 158).

Since it can be argued that the creation, diffusion, and use of systems knowledge is the classical task of the sciences $[93,99]$, most of the characteristics of latent public goods (as outlined above) can be expected to also hold for systems knowledge in terms of its relatedness, cumulative properties, and codifiability. Special features to be considered when dealing with systems knowledge in the context of a transformation towards an SKBBE will be twofold: First, systems knowledge may be quite sticky, that is, it may require much effort to be transferred. This is owed to the fact that departing from linear cause-and-effect thinking and starting to think in systems still requires quite some intellectual effort on the side of the knowledge carrier (see also [128], on a related note). Second, systems knowledge can be expected to be strongly dispersed among different disciplines and knowledge bases of great cognitive distances, such as - with recourse to the example of ILUC - economics, agricultural sciences, complexity science, and other (social and natural) sciences.

\subsection{Normative Knowledge}

According to Abson and colleagues ([35], p. 32), "[n]ormative knowledge encompasses both knowledge on desired system states (normative goals or target knowledge...) and knowledge related to the rationalization of value judgements associated with evaluating alternative potential states of the world (as informed by systems knowledge...)". In the context of an SKBBE, it becomes clear that normative knowledge must refer not only to directionality, responsibility, and legitimacy issues in IS (as discussed in [3]) but also to the targets of the interconnected physical, biological, social, political, and other systems (e.g., [102]). Thereby, for the transformation of knowledge into "something valuable" within IS (cf. [27]), the dedication of IS to an SKBBE also implies that the goals of "international competitiveness and economic growth" (cf. [27]) must be adjusted and re-aligned with what is considered something valuable in conjunction with the other interconnected (sub-)systems (for example, social and ecological ones) (see also $[129,130]$ on the related discussion about orientation failure in IS).

Yet, one of the major issues with prior systemic approaches to sustainability transformations, in general, seems to be that they tend to oversimplify the complexity of normative knowledge and value systems by presuming a consensus about the scale and importance of sustainability-related goals and visions [131]. As, for instance, Miller and colleagues [132] claim, "[i]nquiries into values are largely absent from the mainstream sustainability science agenda" ([132], p. 241). However, sustainability is a genuinely normative phenomenon [93] and knowledge related to norms, values, and desired goals that indicate the necessity for and direction of change is essential for the successful systemic change towards a sustainable bioeconomy (and not just any bioeconomy for the sake of endowing the 
biotechnology sector). Norms, values, and narratives of sustainability are regularly contested and contingent on diverse and often conflicting and (co-)evolving worldviews [3,131-138].

Similar ambiguity can be observed in the context of the bioeconomy (e.g., [15,139]). When taking the complexity of normative knowledge seriously, it may even be impossible to define globally effective rules, norms, or values (in terms of a universal paradigm for an SKBBE) [21]. Arguably, it may be more important to empower actors within IS to "apply, negotiate and reconcile norms and principles based on the judgements of multiple stakeholders" ([140], p. 12). The creation of normative knowledge for an SKBBE can thus be expected to depend on different initial conditions such as the cultural context, whereas the diffusion of a globally effective canon of practices for an SKBBE is highly unlikely (see also [141]). Normative knowledge for an SKBBE is, therefore, intrinsically local in character despite the fact that sustainable development is a global endeavor.

Moreover, the creation of normative knowledge is shaped by cultural evolutionary processes (e.g., $[138,142-149])$. This means, for example, that both subject rules that shape the sustainability goals of the individual carriers (for example, what they consider good or bad) and object rules that determine what is legitimate and important within a social system or IS are subject to path dependence, competition, and feedback at the level of the underlying ideas (e.g., $[58,131,150,151])$. The diffusion of normative knowledge about the desired states of a system is therefore always contingent on its context specificity and dependent on cultural evolution. In Boyd and Richerson's words, "people acquire beliefs, attitudes, and values both by teaching and by observing the behavior of others. Culture is not behavior; culture is information ... that, together with individuals' genes and their environments, determines their behavior" ([145], p. 74). While many object rules are codifiable as laws and formal institutions, most subject rules can be assumed to remain tacit so that normative knowledge consists of a combination of tacit and codified knowledge. Of course, "people are not simply rule bound robots who carry out the dictates of their culture" ([145], p. 72), but rules can often work subconsciously to evolve institutions (e.g., [152]) and shared paradigms that span the "bounded performative space" of an IS (see, e.g., [3], on a related note).

Consequently, when referring to normative knowledge and the constituting values and belief systems, we are not only dealing with the competition and evolution of knowledge at the level of rules and ideas driven by (co-)evolutionary processes across the societal sub-systems of individuals, the market, the state, civil society, and nature [106]. To a great extent, the cognitive distances of competing carriers within sub-systems and their conflicting strategies can also pose serious impediments to normative knowledge creation, diffusion, and use. This complex interrelation may, thus, be understood from a multilevel perspective with feedback between worldviews, visions, paradigms, the Earth system, regimes, and niches [153].

\subsection{Transformative Knowledge}

Transformative knowledge can, in the context of this article, be understood as knowledge about how to accelerate and influence the ongoing transformation towards an SKBBE. As, for instance, Abson and colleagues [35] explain, this type of knowledge is necessary for the development of tangible strategies to transform systems (based on systems knowledge) towards the goals derived from normative knowledge. Theoretical and practical understanding must be attained to afford transitions from the current to the desired states of the respective system(s), which will require a mix of codified and tacit elements. Creating transformative knowledge will encompass the acquisition of skills and knowledge about how to effect systemic changes, or, as Almudi and Fatas-Villafranca put it, how to deliberately shape the evolutionary processes in other sub-systems (a mechanism referred to as promotion [106]). Although wicked problems that necessitate these changes are most often global in nature, their solution strategies will have to be adapted to the local conditions [97]. While global concepts and goals for a bioeconomy may be relatively easy to agree upon, the concrete measures and resource allocation will be negotiated and disputed at the regional and local scales [154]. This renders transformative knowledge in IS exceptionally local. 
In line with the necessity for a change of goals and values, scholars of the educational sciences argue that effective transformative knowledge will also require a revision of inherited individual value frames and assumptions on the side of the knowledge carriers themselves [155]. This process of fundamentally challenging personal worldviews inherent in the absorption of truly transformative knowledge makes this type of knowledge extremely sticky and inhibited by lock-ins and path dependence. For a transformation from a fossil to a bio-based economy, the collective habituation to a seemingly endless and cheap supply of fossil resources and the ostensibly infinite capacity of ecosystems to absorb emissions and waste must be overcome. In line with findings from cultural evolution and the RBA, sustainability education research has also pointed to the importance of acknowledging that human action is driven not only by cognitive knowledge but also unconsciously by "deeper" levels of knowing such as norms, assumptions, values, or beliefs [156]. Consequently, only when being effective on these different levels of consciousness can transformative knowledge unfold its full potential to enable its carriers to induce behavioral change in themselves, a community, or the society. Put differently, the agents of sub-systems will only influence the replication and selection processes according to sustainable values in other sub-systems (via promotion) if they expect advantages in individual and social well-being [106].

Besides systems and normative knowledge, transformative knowledge thus requires the skills to affect deeper levels of knowing and meaning, thereby influencing more immediate and conscious levels of (cognitive and behavioral) rules, ideas, theories, and action $[157,158]$. Against this backdrop, it may come as no surprise that the prime minister of the German state of Baden-Wuerttemberg, member of the green party, has so far failed to push state policies towards a mobility transformation away from individual transport on the basis of combustion technology. In an interview, he made it quite clear that although he has his chauffeur drive him in a hybrid car on official trips, in his private life he "does what he considers right" by driving "a proper car"—namely a Diesel [159].

From what we have elaborated regarding the characteristics of transformative knowledge, we must conclude that its creation requires a learning process on multiple levels. It must be kept in mind that it can only be absorbed if the systemic understanding of the problem and a vision regarding the desired state are present, that is, if a certain level of capacity to absorb transformative knowledge is given. Furthermore, Grunwald [93] argues that the creation of transformative knowledge must be reflexive. In a similar vein, Lindner and colleagues stress the need for reflexivity in IS, and they propose various quality criteria for reflexive IS [130]. In terms of its diffusion and use, transformative knowledge is thought to become effective only if it is specific to the context and if its carriers have internalized the necessity for transformation by challenging their personal assumptions and values. Consequently, since values and norms have evolved via cultural evolution, transformative knowledge also needs to include knowledge about how to influence the cultural evolutionary processes (e.g., [133,160-163]). To take up Brewer's culture design approach, "change processes can only be guided if their evolutionary underpinnings are adequately understood. This is the role for approaches and insights from cultural evolution" ([160], p. 69).

\section{Policy-Relevant Implications}

\subsection{Knowledge-Related Gaps in Current Bioeconomy Policies}

The transformation towards an SKBBE must obviously be guided by strategies derived from using transformative knowledge which is, by definition, based on the other relevant types comprising dedicated knowledge. We suspect that the knowledge which guided political decision-makers in developing and implementing current bioeconomy policies so far has, in some respect, not been truly transformative. Important processes of creating, diffusing, and using systems and, especially normative knowledge, have not sufficiently been facilitated. We propose how more detailed insights into the characteristics of dedicated knowledge can be used to inform policymakers in improving their transformative capacities. Based on the example of two common issues of critique in the current 
bioeconomy policy approaches, we will substantiate our knowledge-based argument. Bioeconomy policies have been identified (i) to be biased towards economic goals and, therefore, take an unequal account of all three dimensions of sustainability [21,164-168]; and, to some extent related to it; (ii) to only superficially integrate all relevant stakeholders into policy making [21,165,169-173].

Bioeconomy policies brought forward by the European Union (EU) and several nations have been criticized for a rather narrow techno-economic emphasis. While using the term sustainable as an attribute to a range of goals and principles frequently, the EU bioeconomy framework, for example, still overemphasizes the economic dimension. This is reflected by the main priority areas of various political bioeconomy agendas which remain quite technocratic: keywords include biotechnology, eco-efficiency, competitiveness, innovation, economic output, and industry in general [14,164]. The EU's proposed policy action along the three large areas (i) the investment in research, innovation and skills; (ii) the reinforcement of policy interaction and stakeholder engagement; and (iii) the enhancement of markets and competitiveness in bioeconomy sectors ([174], p. 22), reveals a strong focus on fostering economically relevant and technological knowledge creation. In a recent review [175] of its 2012 Bioeconomy Strategy [174] the European Commission (EC) did indeed observe some room for improvement with regard to more comprehensive bioeconomy policies by acknowledging that "the achievement of the interlinked bioeconomy objectives requires an integrated (i.e., cross-sectoral and cross-policy) approach within the EC and beyond. This is needed in order to adequately address the issue of multiple trade-offs but also of synergies and interconnected objectives related to bioeconomy policy (e.g., sustainability and protection of natural capital, mitigating climate change, food security)" ([175], p. 25).

An overemphasis on economic aspects of the bioeconomy in implementation strategies is likely to be rooted in an insufficient stock of systems knowledge. If the bioeconomy is meant to "radically change [Europe's] approach to production, consumption, processing, storage, recycling and disposal of biological resources" ([174], p. 8) and to "assure over the long term the prosperity of modern societies" ([4], p. 2), the social and the ecological dimension have to play equal roles. Furthermore, the systemic interplay between all three dimensions of sustainability must be understood and must find its way into policy making via systems knowledge. While the creation of systems knowledge within the individual disciplines does not seem to be the issue (considering, for example, advances in Earth system sciences, agriculture, and political sciences), its interdisciplinary diffusion and use seem to lag behind (see also [160], on a related note). The prevalent characteristics of this knowledge relevant for its diffusion have been found to be stickiness and dispersal (see Section 3.1 above). To reduce the stickiness of systems knowledge and, thus, improve its diffusion and transfer, long-term policies need to challenge the fundamental principles still dominating in education across disciplines and across school levels: linear cause-and-effect thinking must be abandoned in favor of systemic ways of thinking. To overcome the wide dispersal of bioeconomically relevant knowledge across academic disciplines and industrial sectors, policies must encourage inter- and transdisciplinary research even more and coordinate knowledge diffusion across mental borders. This, in turn, calls for strategies that facilitate connecting researchers across disciplines and with practitioners as well as translating systems knowledge for the target audience (e.g., [74]). Only then can systems knowledge ultimately be used for informing the creation processes of transformative knowledge.

This brings us to the second issue of bioeconomy policies mentioned above: the failure of bioeconomy strategies to involve all stakeholders in a sincere and open dialogue on goals and paths towards (a sustainable) bioeconomy $[169,170,173]$. Their involvement in the early stages of a bioeconomy transformation is not only necessary for receiving sufficient acceptance of new technologies and the approval of new products $[168,170]$. These aspects—which, again, mainly affect the short-term economic success of the bioeconomy-are addressed well across various bioeconomy strategies. However, "[a]s there are so many issues, trade-offs and decisions to be made on the design and development of the bioeconomy, a commitment to participatory governance that engages the general public and key stakeholders in an open and informed dialogue appears vital" ([168], p. 2603; 
italics added). From the perspective of dedicated knowledge, there is a reason why failing to integrate the knowledge, values, and worldviews of the people affected will seriously impede the desired transformation: the processes of creation, diffusion, and use of normative knowledge and transformative knowledge are contingent on the input of a broad range of stakeholders-basically, of everyone who will eventually be affected by the transformation. The use of normative knowledge (that is, the agreement upon common goals), as well as the use of transformative knowledge (that is, the definition of transformation strategies), have both been identified to be intrinsically local and context-specific (see Sections 3.2 and 3.3). A policy taking account of these characteristics will adopt mechanisms to enable citizens to take part in societal dialogue which must comprise three tasks: offering suitable participatory formats, educating people to become responsible citizens, and training transdisciplinary capabilities to overcome cognitive distances between different mindsets as well as to reconcile global goals with local requirements. In this respect, there has been a remarkable development at the European level: while the German government is still relying on the advice of a Bioeconomy Council representing only the industry and academia for developing the bioeconomy policy [154], the recently reconstituted delegates of the European Bioeconomy Panel represent a variety of societal groups: "business and primary producers, policymakers, researchers, and civil society organisations" ([175], p. 13). Unsurprisingly, their latest publication, the bioeconomy stakeholders' manifesto, gives some recommendations that clearly reflect the broad basis of stakeholders involved, especially concerning education, skills, and training [176].

For a structured overview of the elements of dedicated knowledge and their consideration by current bioeconomy policy approaches, see Table 1 .

\subsection{Promising (But Fragmented) Building Blocks for Improved SKBBE Policies}

Although participatory approaches neither automatically decrease the cognitive distances between stakeholders nor guarantee that the solution strategies agreed upon are based on the most appropriate (systems and normative) knowledge [95], an SKBBE cannot be achieved in a top-down manner. Consequently, the involvement of stakeholders confronts policymakers with the roles of coordinating agents and knowledge brokers $[74,75,77,177]$. Once a truly systemic perspective is taken up, the traditional roles of different actors (for example, the state, non-governmental organizations, private companies, consumers) become blurred (see also [178-180]), which has already been recognized in the context of environmental governance and prompted Western democracies to adopt more participatory policy approaches [181]. A variety of governance approaches exist, ranging from adaptive governance (e.g., [182-184]) and reflexive governance (e.g., [130,185]) to Earth system governance (e.g., $[18,101,186])$ and various other concepts (e.g., $[107,187-190])$. Without digressing too much into debates about the differences and similarities of systemic governance approaches, we can already contend that the societal roots of many of the sustainability-related wicked problems clearly imply that social actors are not only part of the problem but must also be part of the solution. Against this background, transdisciplinary research and participatory approaches such as co-design and co-production of knowledge have recently gained momentum with good reason (e.g., [37,191-198]) and are also promising in the context of the transformation towards an SKBBE. Yet, the question remains why only very few, if any, bioeconomy policies have taken participatory approaches and stakeholder engagement seriously (see, e.g., [170,199], on a related discussion). 
Table 1. The elements of dedicated knowledge in the context of SKBBE policies.

\begin{tabular}{|c|c|c|c|c|}
\hline $\begin{array}{l}\text { Central Knowledge } \\
\text { Types as Elements of } \\
\text { Dedicated Knowledge }\end{array}$ & General Meaning & $\begin{array}{l}\text { Sustainability and } \\
\text { Bioeconomy-Related } \\
\text { Instrumental Value }\end{array}$ & $\begin{array}{c}\text { Most Prevalent Characteristics } \\
\text { Regarding Creation, } \\
\text { Diffusion and Use }\end{array}$ & $\begin{array}{l}\text { Consideration by } \\
\text { Current Bioeconomy } \\
\text { Policy Approaches }\end{array}$ \\
\hline $\begin{array}{l}\text { Economically } \\
\text { relevant knowledge }\end{array}$ & $\begin{array}{l}\text { Knowledge necessary to create } \\
\text { economic value. }\end{array}$ & $\begin{array}{l}\text { Knowledge necessary to create } \\
\text { economic value in line with } \\
\text { the resources, processes, } \\
\text { and principles of } \\
\text { biological systems. }\end{array}$ & $\begin{array}{l}\text { Latent public good, depending } \\
\text { on the technology in question. }\end{array}$ & Adequately considered. \\
\hline Systems knowledge & $\begin{array}{l}\text { Descriptive, interdisciplinary } \\
\text { understanding of } \\
\text { relevant systems. }\end{array}$ & $\begin{array}{l}\text { Understanding of the dynamics } \\
\text { and interactions between } \\
\text { biological, economic, } \\
\text { and social systems. }\end{array}$ & $\begin{array}{l}\text { Sticky and strongly dispersed } \\
\text { between disciplines. }\end{array}$ & Insufficiently considered. \\
\hline Normative knowledge & $\begin{array}{l}\text { Knowledge about desired } \\
\text { system states to formulate } \\
\text { systemic goals. }\end{array}$ & $\begin{array}{l}\text { (Knowledge of) Collectively } \\
\text { developed goals for } \\
\text { sustainable bioeconomies. }\end{array}$ & $\begin{array}{l}\text { Intrinsically local, } \\
\text { path-dependent, and } \\
\text { context-specific; } \\
\text { but sustainability as } \\
\text { a global endeavor. }\end{array}$ & Partially considered. \\
\hline Transformative knowledge & $\begin{array}{l}\text { Know-how for challenging } \\
\text { worldviews and developing } \\
\text { tangible strategies to facilitate } \\
\text { the transformation from current } \\
\text { system to target system. }\end{array}$ & $\begin{array}{l}\text { Knowledge about strategies to } \\
\text { govern the transformation } \\
\text { towards an SKBBE. }\end{array}$ & $\begin{array}{l}\text { Local and context-specific, } \\
\text { strongly sticky, } \\
\text { and path-dependent. }\end{array}$ & Partially considered. \\
\hline
\end{tabular}


To better acknowledge the characteristics of dedicated knowledge, we can propose a combination of four hitherto rather fragmented but arguably central frameworks that may be built on to improve bioeconomy policy agendas in terms of creating, diffusing, and using dedicated knowledge (note that the proposed list is non-exhaustive but may serve as a starting point for developing more adequate knowledge-based bioeconomy policies):

- Consider the roles of policymakers and policy making from a co-evolutionary perspective (see also [138]), where the "state" is conceived as one of several sub-systems (for example, next to the individuals, civil society, the market, and nature) shaping contemporary capitalist societies [106]. Through the special co-evolutionary mechanism of promotion, political entities are able to deliberately influence the propagation (or retention) of certain knowledge, skills, ideas, values, or habits within other sub-systems and, thereby, trigger change in the whole system [106].

- Take up insights from culture design (e.g., [133,160-163,200]) and findings on transmission and learning biases in cultural evolution (e.g., [201-203]) that may help to explain and eventually overcome the stickiness and locality of both systems and normative knowledge and thereby increase the absorptive capacities of DIS actors for dedicated knowledge.

- Use suggestions from the literature on adaptive governance such as the combination of indigenous knowledge with scientific knowledge (to overcome path dependencies), continuous adaptation of transformative knowledge to new systems knowledge (to avoid lock-ins), embracing uncertainty (accepting that the behavior of systems can never be completely understood and anticipated), and the facilitation of self-organization (e.g., $[183,184]$ ) by empowering citizens to participate in the responsible co-creation, diffusion, and use of dedicated knowledge.

- Apply reflexive governance instruments as guideposts for DIS, including principles of transdisciplinary knowledge production, experimentation, and anticipation (creating systems knowledge), participatory goal formulation (creating and diffusing normative knowledge), and interactive strategy development (using transformative knowledge) $([130,204])$ for the bioeconomy transformation.

In summary, we postulate that for more sustainable bioeconomy policies, we need more adequate knowledge policies.

\section{Conclusions}

Bioeconomy policies have not effectively been linked to findings and approved methods of sustainability sciences. The transformation towards a bioeconomy, thus, runs into the danger of becoming an unsustainable and purely techno-economic endeavor. Effective public policies that take due account of the knowledge dynamics underlying transformation processes are required. In the context of sustainability, it is not enough to just improve the capacity of an IS for creating, diffusing, and using economically relevant knowledge. Instead, the IS must become more goal-oriented and dedicated to tackling wicked problems [3,205]. Accordingly, for affording such systemic dedication to the transformation towards an SKBBE, it is central to consider dedicated knowledge (that is, a combination of the understanding of economically relevant knowledge with systems knowledge, normative knowledge, and transformative knowledge).

Drawing upon our insights into such dedicated knowledge, we can better understand why current policies have not been able to steer the bioeconomy transformation onto a sustainable path. We admit that recent policy revision processes (e.g., $[173,175,176,206-208]$ )—especially in terms of viewing the transition to a bioeconomy as a societal transformation, a focus on participatory approaches, and a better coordination of policies and sectors-are headed in the right direction. However, we suggest that an even stronger focus on the characteristics of dedicated knowledge and its creation, diffusion, and use in DIS is necessary for the knowledge-based bioeconomy to become truly sustainable. These characteristics include stickiness, locality, context specificity, dispersal, and path dependence. Taking dedicated knowledge more seriously entails that the currently most influential 
players in bioeconomy governance (that is, the industry and academia) need to display a serious willingness to learn and acknowledge the value of opening up the agenda-setting discourse and allow true participation of all actors within the respective DIS. Although in this article, we focus on the role of knowledge, we are fully aware of the fact that in the context of an SKBBE, other points of systemic intervention exist and must also receive appropriate attention in future research and policy endeavors $[127,209]$.

While many avenues for future inter- and transdisciplinary research exist, the next steps may include

- enhancing systems knowledge by analyzing which actors and network dynamics are universally important for a successful transformation towards an SKBBE and which are contingent on the respective variety of a bioeconomy,

- an inquiry into knowledge mobilization and, especially the role(s) of knowledge brokers for the creation, diffusion, and use of dedicated knowledge (for example, installing regional bioeconomy hubs),

- researching the implications of extending the theory of knowledge to other relevant disciplines,

- $\quad$ assessing the necessary content of academic and vocational bioeconomy curricula for creating bioeconomy literacy beyond techno-economic systems knowledge,

- applying and refining the RBA to study which subject rules and which object rules are most important for supporting sustainability transformations,

- $\quad$ and many more.

Author Contributions: S.U., M.P.S. and K.B.B. contributed equally as lead authors. K.B.B. mainly authored Section 2 with contributions from M.M. S.U. and M.P.S. mainly authored Sections 3 and 4. M.M. and A.P. were involved in the overall supervision and provided input to all sections of the draft. All authors read carefully and approved the final version of the manuscript.

Funding: This research received no specific grant but A.P. and M.M. gratefully acknowledge financial support from the Dieter Schwarz Stiftung.

Acknowledgments: The authors would like to thank the participants of the 10th European Meeting on Applied Evolutionary Economics (EMAEE), 31 May-3 June 2017, in Strasbourg for valuable comments on an earlier draft. Moreover, the authors are grateful for Lukas Zuschrott's help with formatting the final article and references.

Conflicts of Interest: The authors declare no conflict of interest.

\section{References}

1. Rittel, H.W.J.; Webber, M.M. Dilemmas in a general theory of planning. Policy Sci. 1973, 4, 155-169. [CrossRef]

2. Pohl, C.; Truffer, B.; Hirsch Hadorn, G. Addressing wicked problems through transdisciplinary research. In The Oxford Handbook of Interdisciplinarity; Frodeman, R., Klein, J.T., Pacheco, R.C.S., Eds.; Oxford University Press: Oxford, UK, 2017; pp. 319-331.

3. Schlaile, M.P.; Urmetzer, S.; Blok, V.; Andersen, A.; Timmermans, J.; Mueller, M.; Fagerberg, J.; Pyka, A. Innovation systems for transformations towards sustainability? Taking the normative dimension seriously. Sustainability 2017, 9, 2253. [CrossRef]

4. BMBF; BMEL. Bioeconomy in Germany: Opportunities for a Bio-Based and Sustainable Future; Federal Ministry of Education and Research \& Federal Ministry of Food and Agriculture: Berlin/Bonn, Germany, 2015.

5. Dabbert, S.; Lewandowski, I.; Weiss, J.; Pyka, A. (Eds.) Knowledge-Driven Developments in the Bioeconomy; Springer: Cham, Switzerland, 2017.

6. Lewandowski, I. (Ed.) Bioeconomy; Springer International Publishing: Cham, Switzerland, 2018.

7. Philp, J. The bioeconomy, the challenge of the century for policy makers. New Biotechnol. 2018, 40, 11-19. [CrossRef] [PubMed]

8. von Braun, J. Bioeconomy: The New Transformation of Agriculture, Food, and Bio-Based Industries, Implications for Emerging Economies. 2017. Available online: http:/ / www.ifpri.org/event/bioeconomy$\% \mathrm{E} 2 \% 80 \% 93$-new-transformation-agriculture-food-and-bio-based-industries- $\% \mathrm{E} 2 \% 80 \% 93$-implications (accessed on 15 April 2018). 
9. The White House. National Bioeconomy Blueprint; The White House: Washington, DC, USA, 2012.

10. El-Chichakli, B.; von Braun, J.; Lang, C.; Barben, D.; Philp, J. Five cornerstones of a global bioeconomy. Nature 2016, 535, 221-223. [CrossRef] [PubMed]

11. Virgin, I.; Fielding, M.; Fones Sundell, M.; Hoff, H.; Granit, J. Benefits and challenges of a new knowledge-based bioeconomy. In Creating Sustainable Bioeconomies: The Bioscience Revolution in Europe and Africa; Virgin, I., Morris, E.J., Eds.; Routledge: Abingdon, UK, 2017; pp. 11-25.

12. Pyka, A.; Prettner, K. Economic growth, development, and innovation: The transformation towards a knowledge-based bioeconomy. In Bioeconomy; Lewandowski, I., Ed.; Springer International Publishing: Cham, Switzerland, 2018; pp. 331-342.

13. DECHEMA Gesellschaft für Chemische Technik und Biotechnologie e.V. on behalf of the German Presidency of the Council of the European Union. En Route to the Knowledge-Based Bio-Economy-Cologne Paper. 2007. Available online: http://dechema.de/dechema_media/Cologne_Paper-p-20000945.pdf (accessed on 1 April 2018).

14. Staffas, L.; Gustavsson, M.; McCormick, K. Strategies and policies for the bioeconomy and bio-based bconomy: An analysis of official national approaches. Sustainability 2013, 5, 2751-2769. [CrossRef]

15. Bugge, M.; Hansen, T.; Klitkou, A. What is the bioeconomy? A review of the literature. Sustainability 2016, 8, 691. [CrossRef]

16. Pyka, A. Dedicated innovation systems to support the transformation towards sustainability: Creating income opportunities and employment in the knowledge-based digital bioeconomy. J. Open Innov. 2017, 3, 385. [CrossRef]

17. Pyka, A.; Buchmann, T. Die Transformation zur wissensbasierten Bioökonomie. In Technologie, Strategie und Organisation; Burr, W., Stephan, M., Eds.; Springer: Wiesbaden, Germany, 2017; pp. 333-361.

18. Patterson, J.; Schulz, K.; Vervoort, J.; van der Hel, S.; Widerberg, O.; Adler, C.; Hurlbert, M.; Anderton, K.; Sethi, M.; Barau, A. Exploring the governance and politics of transformations towards sustainability. Environ. Innov. Soc. Trans. 2017, 24, 1-16. [CrossRef]

19. Morone, P. The times they are a-changing: Making the transition toward a sustainable economy. Biofuels Bioprod. Biorefin. 2016, 10, 369-377. [CrossRef]

20. Westley, F.; Olsson, P.; Folke, C.; Homer-Dixon, T.; Vredenburg, H.; Loorbach, D.; Thompson, J.; Nilsson, M.; Lambin, E.; Sendzimir, J.; et al. Tipping toward sustainability: Emerging pathways of transformation. Ambio 2011, 40, 762-780. [CrossRef] [PubMed]

21. Pfau, S.; Hagens, J.; Dankbaar, B.; Smits, A. Visions of sustainability in bioeconomy research. Sustainability 2014, 6, 1222-1249. [CrossRef]

22. Freeman, C. Technology Policy and Economic Performance: Lessons from Japan; Pinter: London, UK, 1987.

23. Freeman, C. Systems of Innovation: Selected Essays in Evolutionary Economics; Edward Elgar: Cheltenham, UK, 2008.

24. Lundvall, B.-Å. (Ed.) National Systems of Innovation: Towards a Theory of Innovation and Interactive Learning; Pinter: London, UK, 1992.

25. Nelson, R.R. (Ed.) National Innovation Systems: A Comparative Study; Oxford University Press: New York, NY, USA, 1993.

26. Edquist, C. (Ed.) Systems of Innovation; Routledge: London, UK, 1997.

27. Gregersen, B.; Johnson, B. Learning economies, innovation systems and European integration. Reg. Stud. 1997, 31, 479-490. [CrossRef]

28. Lundvall, B.-Å.; Johnson, B. The learning economy. J. Ind. Stud. 1994, 1, 23-42. [CrossRef]

29. Lundvall, B.- $\AA$. The economics of knowledge and learning. In Product Innovation, Interactive Learning and Economic Performance; Christensen, J.L., Lundvall, B.-Å., Eds.; Elsevier JAI: Amsterdam, The Netherlands, 2004; pp. 21-42.

30. Lundvall, B.-Å. Post script: Innovation system research-Where it came from and where it might go. In National Systems of Innovation: Toward a Theory of Innovation and Interactive Learning; Lundvall, B.-Å., Ed.; Anthem Press: London, UK, 2010; pp. 317-349.

31. OECD. Knowledge Management in the Learning Society: Education and Skills; OECD: Paris, France, 2000.

32. Edquist, C. Systems of innovation: Perspectives and challenges. In The Oxford Handbook of Innovation; Fagerberg, J., Mowery, D.C., Nelson, R.R., Eds.; Oxford University Press: Oxford, UK, 2005; pp. 181-208.

33. Martin, B.R. Twenty challenges for innovation studies. Sci. Public Policy 2016, 43, 432-450. [CrossRef] 
34. ProClim. Research on Sustainability and Global Change-Visions in Science Policy by Swiss Researchers; ProClim: Berne, Switzerland, 2017.

35. Abson, D.J.; von Wehrden, H.; Baumgärtner, S.; Fischer, J.; Hanspach, J.; Härdtle, W.; Heinrichs, H.; Klein, A.M.; Lang, D.J.; Martens, P.; et al. Ecosystem services as a boundary object for sustainability. Ecol. Econ. 2014, 103, 29-37. [CrossRef]

36. Wiek, A.; Lang, D.J. Transformational sustainability research methodology. In Sustainability Science; Heinrichs, H., Martens, P., Michelsen, G., Wiek, A., Eds.; Springer: Dordrecht, The Netherlands, 2016; pp. 31-41.

37. von Wehrden, H.; Luederitz, C.; Leventon, J.; Russell, S. Methodological challenges in sustainability science: A call for method plurality, procedural rigor and longitudinal research. Chall. Sustain. 2017, 5. [CrossRef]

38. Knierim, A.; Laschewski, L.; Boyarintseva, O. Inter- and transdisciplinarity in bioeconomy. In Bioeconomy; Lewandowski, I., Ed.; Springer International Publishing: Cham, Switzerland, 2018; pp. 39-72.

39. English Oxford Living Dictionaries. Definition of Knowledge in English. Available online: https://en. oxforddictionaries.com/definition/knowledge (accessed on 13 April 2018).

40. Cambridge University Press. Meaning of "Knowledge" in the English Dictionary. 2018. Available online: https:/ / dictionary.cambridge.org/dictionary/english/knowledge (accessed on 16 April 2018).

41. Zagzebski, L. What is knowledge? In The Blackwell Guide to Epistemology; Greco, J., Sosa, E., Eds.; Blackwell Publishing Ltd.: Malden, MA, USA, 1999; pp. 92-116.

42. Pyka, A.; Gilbert, N.; Ahrweiler, P. Agent-based modelling of innovation networks: The fairytale of spillover. In Innovation Networks: New Approaches in Modelling and Analyzing; Pyka, A., Scharnhorst, A., Eds.; Springer: Heidelberg, Germany, 2009; pp. 101-126.

43. Arrow, K. Economic welfare and the allocation of resources for invention. In The Rate and Direction of Inventive Activity: Economic and Social Factors; Nelson, R.R., Ed.; Princeton University Press: Princeton, NJ, USA, 1962; pp. 609-626.

44. Audretsch, D.B.; Leyden, D.P.; Link, A.N. Regional appropriation of university-based knowledge and technology for economic development. Econ. Dev. Q. 2013, 27, 56-61. [CrossRef]

45. Acs, Z.J.; Audretsch, D.B.; Lehmann, E.E. The knowledge spillover theory of entrepreneurship. Small Bus. Econ. 2013, 41, 757-774. [CrossRef]

46. Solow, R.M. A Contribution to the theory of economic growth. Q. J. Econ. 1956, 70, 65. [CrossRef]

47. Solow, R.M. Technical change and the aggregate production function. Rev. Econ. Stat. 1957, $39,312$. [CrossRef]

48. Nelson, R.R. What is private and what is public about technology? Sci. Technol. Hum. Values 1989, 14, 229-241. [CrossRef]

49. Dopfer, K.; Potts, J. The General Theory of Economic Evolution; Routledge: London, UK, 2008.

50. Boschma, R. Proximity and innovation: A critical assessment. Reg. Stud. 2005, 39, 61-74. [CrossRef]

51. Foray, D.; Mairesse, J. The knowledge dilemma in the geography of innovation. In Institutions and Systems in the Geography of Innovation; Feldman, M.P., Massard, N., Eds.; Springer: New York, NY, USA, 2002; pp. $35-54$.

52. Dosi, G. Technological paradigms and technological trajectories. Res. Policy 1982, 11, 147-162. [CrossRef]

53. Rizzello, S. Knowledge as a path-dependence process. J. Bioecon. 2004, 6, 255-274. [CrossRef]

54. Morone, P.; Taylor, R. Knowledge Diffusion and Innovation: Modelling Complex Entrepreneurial Behaviours; Edward Elgar: Cheltenham, UK, 2010.

55. Vermeulen, B.; Pyka, A. The role of network topology and the spatial distribution and structure of knowledge in regional innovation policy: A calibrated agent-based model study. Comput. Econ. 2017, 11, 23. [CrossRef]

56. Arthur, W.B. The structure of invention. Res. Policy 2007, 36, 274-287. [CrossRef]

57. Schumpeter, J.A. Theorie der wirtschaftlichen Entwicklung; Duncker \& Humblot: Leipzig, Germany, 1911.

58. Schlaile, M.P.; Zeman, J.; Mueller, M. It's a match! Simulating compatibility-based learning in a network of networks. J. Evol. Econ. 2018, in press.

59. Frenken, K.; van Oort, F.; Verburg, T. Related variety, unrelated variety and regional economic growth. Reg. Stud. 2007, 41, 685-697. [CrossRef]

60. Rooney, D.; Hearn, G.; Mandeville, T.; Joseph, R. Public Policy in Knowledge-Based Economies: Foundations and Frameworks; Edward Elgar: Cheltenham, UK, 2003.

61. Adolf, M.; Stehr, N. Knowledge; Routledge: London, UK, 2014. 
62. Morone, P. Knowledge, innovation and internationalisation: A roadmap. In Knowledge, Innovation and Internationalization; Morone, P., Ed.; Taylor and Francis: Hoboken, NJ, USA, 2013; pp. 1-13.

63. Polanyi, M. The Tacit Dimension; University of Chicago Press: Chicago, IL, USA, 1966.

64. Galunic, D.C.; Rodan, S. Resource recombinations in the firm: Knowledge structures and the potential for Schumpeterian innovation. Strat. Mgmt. J. 1998. [CrossRef]

65. Antonelli, C. The evolution of the industrial organisation of the production of knowledge. Camb. J. Econ. 1999, 23, 243-260. [CrossRef]

66. Nonaka, I. A dynamic theory of organizational knowledge creation. Organ. Sci. 1994, 5, 14-37. [CrossRef]

67. Szulanski, G. Sticky Knowledge: Barriers to Knowing in the Firm; SAGE: London, UK, 2003.

68. von Hippel, E. "Sticky information" and the locus of problem solving: Implications for innovation. Manag. Sci. 1994, 40, 429-439. [CrossRef]

69. Potts, J. Knowledge and markets. J. Evol. Econ. 2001, 11, 413-431. [CrossRef]

70. Cohen, W.M.; Levinthal, D.A. Innovation and learning: The two faces of R \& D. Econ. J. 1989, 99, 569-596.

71. Cohen, W.M.; Levinthal, D.A. Absorptive capacity: A new perspective on learning and innovation. Admin. Sci. Q. 1990, 35, 128-152. [CrossRef]

72. Nooteboom, B.; van Haverbeke, W.; Duysters, G.; Gilsing, V.; van den Oord, A. Optimal cognitive distance and absorptive capacity. Res. Policy 2007, 36, 1016-1034. [CrossRef]

73. Bogner, K.; Mueller, M.; Schlaile, M.P. Knowledge diffusion in formal networks: The roles of degree distribution and cognitive distance. Int. J. Comput. Econ. Econom. 2018, in press.

74. Bennet, A.; Bennet, D. Knowledge Mobilization in the Social Sciences and Humanities: Moving from Research to Action; MQI Press: Marlinton, VI, USA, 2007.

75. Jacobson, N.; Butterill, D.; Goering, P. Development of a framework for knowledge translation: Understanding user context. J. Health Serv. Res. Policy 2003, 8, 94-99. [CrossRef] [PubMed]

76. Szulanski, G. The process of knowledge transfer: A diachronic analysis of stickiness. Organ. Behav. Hum. Dec. Process. 2000, 82, 9-27. [CrossRef]

77. Mitton, C.; Adair, C.E.; McKenzie, E.; Patten, S.B.; Waye Perry, B. Knowledge transfer and exchange: Review and synthesis of the literature. Milbank Q. 2007, 85, 729-768. [CrossRef] [PubMed]

78. Adomßent, M. Exploring universities' transformative potential for sustainability-bound learning in changing landscapes of knowledge communication. J. Clean. Prod. 2013, 49, 11-24. [CrossRef]

79. Nyholm, J.; Normann, L.; Frelle-Petersen, C.; Riis, M.; Torstensen, P. Innovation policy in the knowledge-based economy: Can theory guide policy making? In The Globalizing Learning Economy; Archibugi, D., Lundvall, B.-Å., Eds.; Oxford University Press: Oxford, UK, 2001; pp. 239-272.

80. Lundvall, B.-A. Innovation policy in the globalizing learning economy. In The Globalizing Learning Economy; Archibugi, D., Lundvall, B.-Å., Eds.; Oxford University Press: Oxford, UK, 2001; pp. 273-291.

81. Chaminade, C.; Edquist, C. Rationales for public policy intervention in the innovation process: A systems of innovation approach. In The Theory and Practice of Innovation Policy: An International Research Handbook; Smits, R.E., Kuhlmann, S., Shapira, P., Eds.; Edward Elgar: Cheltenham, UK, 2010; pp. 95-114.

82. Smith, K. Interactions in Knowledge Systems: Foundations, Policy Implications and Empirical Methods, STEP Report R-10. 1994. Available online: https://brage.bibsys.no/xmlui/bitstream/handle/11250/ 226741/STEPrapport10-1994.pdf?sequence=1 (accessed on 16 April 2018).

83. Klein Woolthuis, R.; Lankhuizen, M.; Gilsing, V. A system failure framework for innovation policy design. Technovation 2005, 25, 609-619. [CrossRef]

84. Rooney, D.; Hearn, G.; Ninan, A. Knowledge: Concepts, policy, implementation. In Handbook on the Knowledge Economy; Rooney, D., Hearn, G., Ninan, A., Eds.; Edward Elgar: Cheltenham, UK, 2005; pp. 1-16.

85. Barabási, A.-L. Network Science; Cambridge University Press: Cambridge, UK, 2016.

86. Ahrweiler, P.; Keane, M.T. Innovation networks. Mind Soc. 2013, 12, 73-90. [CrossRef]

87. Buchmann, T.; Pyka, A. Innovation networks. In Handbook on the Economics and Theory of the Firm; Dietrich, M., Krafft, J., Eds.; Edward Elgar: Cheltenham, UK, 2012; pp. 466-482.

88. Scharnhorst, A.; Pyka, A. (Eds.) Innovation Networks: New Approaches in Modelling and Analyzing; Springer: Berlin/Heidelberg, Germany, 2009.

89. Edler, J.; Fagerberg, J. Innovation policy: What, why, and how. Oxf. Rev. Econ. Policy 2017, 33, 2-23. [CrossRef] 
90. Soete, L. Is innovation always good? In Innovation Studies: Evolution and Future Challenges; Fagerberg, J., Martin, B.R., Andersen, E.S., Eds.; Oxford Univ. Press: Oxford, UK, 2013; pp. 134-144.

91. Engelbrecht, H.-J. A proposal for a 'national innovation system plus subjective well-being' approach and an evolutionary systemic normative theory of innovation. In Foundations of Economic Change; Pyka, A., Cantner, U., Eds.; Springer: Cham, Switzerland, 2017; pp. 207-231.

92. Lahsen, M. The social status of climate change knowledge: An editorial essay. WIREs Clim. Chang. 2010, 1, 162-171. [CrossRef]

93. Grunwald, A. Working towards sustainable development in the face of uncertainty and incomplete knowledge. J. Environ. Policy Plan. 2007, 9, 245-262. [CrossRef]

94. Wiek, A.; Binder, C. Solution spaces for decision-making-A sustainability assessment tool for city-regions. Environ. Impact Assess. Rev. 2005, 25, 589-608. [CrossRef]

95. Rydin, Y. Re-examining the role of knowledge within planning theory. Plan. Theory 2007, 6, 52-68. [CrossRef]

96. Pyka, A. Transformation of economic systems: The bio-economy case. In Knowledge-Driven Developments in the Bioeconomy; Dabbert, S., Lewandowski, I., Weiss, J., Pyka, A., Eds.; Springer: Cham, Switzerland, 2017; pp. 3-16.

97. Steward, F. Breaking the Boundaries: Transformative Innovation for the Global Good, NESTA Provocation 07. 2008. Available online: http://www.nesta.org.uk/publications/breaking-boundaries (accessed on 16 April 2018).

98. Steward, F. Transformative innovation policy to meet the challenge of climate change: Sociotechnical networks aligned with consumption and end-use as new transition arenas for a low-carbon society or green economy. Technol. Anal. Strat. Manag. 2012, 24, 331-343. [CrossRef]

99. Grunwald, A. Strategic knowledge for sustainable development: The need for reflexivity and learning at the interface between science and society. IJFIP 2004, 1, 150-167. [CrossRef]

100. Schellnhuber, H.-J.; Crutzen, P.J.; Clark, W.C.; Claussen, M.; Held, H. (Eds.) Earth System Analysis for Sustainability; MIT Press in Cooperation with Dahlem University Press: Cambridge, MA, USA, 2004.

101. Biermann, F.; Betsill, M.M.; Gupta, J.; Kanie, N.; Lebel, L.; Liverman, D.; Schroeder, H.; Siebenhüner, B.; Zondervan, R. Earth system governance: A research framework. Int. Environ. Agreem. 2010, 10, 277-298. [CrossRef]

102. Boulding, K.E. The World as a Total System; SAGE: Beverly Hills, CA, USA, 1985.

103. Schramm, M. Der Geldwert der Schöpfung: Theologie, Ökologie, Ökonomie; Schöningh: Paderborn, Germany, 1994.

104. Seidler, R.; Bawa, K.S. Dimensions of sustainable development. In Dimensions of Sustainable Development; Bawa, K.S., Seidler, R., Eds.; Eolss Publishers Co Ltd.: Oxford, UK, 2009; Volume 1, pp. 1-20.

105. Colander, D.C.; Kupers, R. Complexity and the Art of Public Policy: Solving Society's Problems from the Bottom Up; Princeton University Press: Princeton, NJ, USA, 2014.

106. Almudi, I.; Fatas-Villafranca, F. Promotion and coevolutionary dynamics in contemporary capitalism. J. Econ. Issues 2018, 52, 80-102. [CrossRef]

107. Young, O.R. Governing Complex Systems: Social Capital for the Anthropocene; The MIT Press: Cambridge, MA, USA, 2017.

108. Lamberson, P.J.; Page, S.E. Tipping points. QJPS 2012, 7, 175-208. [CrossRef]

109. Wassmann, P.; Lenton, T.M. Arctic tipping points in an Earth system perspective. Ambio 2012, 41, 1-9. [CrossRef] [PubMed]

110. Gladwell, M. The Tipping Point: How Little Things Can Make a Big Difference; Little, Brown and Company: Boston, MA, USA, 2000.

111. Morone, P.; Tartiu, V.E.; Falcone, P. Assessing the potential of biowaste for bioplastics production through social network analysis. J. Clean. Prod. 2015, 90, 43-54. [CrossRef]

112. Scheiterle, L.; Ulmer, A.; Birner, R.; Pyka, A. From commodity-based value chains to biomass-based value webs: The case of sugarcane in Brazil's bioeconomy. J. Clean. Prod. 2018, 172, 3851-3863. [CrossRef]

113. Boulding, K.E. The economics of knowledge and the knowledge of economics. Am. Econ. Rev. 1966, 56, 1-13.

114. Leemans, R.; van Amstel, A.; Battjes, C.; Kreileman, E.; Toet, S. The land cover and carbon cycle consequences of large-scale utilizations of biomass as an energy source. Glob. Environ. Chang. 1996, 6, 335-357. [CrossRef] 
115. Searchinger, T.; Heimlich, R.; Houghton, R.A.; Dong, F.; Elobeid, A.; Fabiosa, J.; Tokgoz, S.; Hayes, D.; $\mathrm{Yu}, \mathrm{T}$.-H. Use of U.S. croplands for biofuels increases greenhouse gases through emissions from land-use change. Science 2008, 319, 1238-1240. [CrossRef] [PubMed]

116. Dopfer, K. Evolutionary economics: A theoretical framework. In The Evolutionary Foundations of Economics; Dopfer, K., Ed.; Cambridge University Press: Cambridge, UK, 2005; pp. 3-55.

117. Dopfer, K. Economics in a cultural key: Complexity and evolution revisited. In The Elgar Companion to Recent Economic Methodology; Davis, J.B., Hands, D.W., Eds.; Edward Elgar: Cheltenham, UK, 2011; pp. 319-340.

118. Dopfer, K. Evolutionary economics. In Handbook on the History of Economic Analysis; Faccarello, G., Kurz, H.-D., Eds.; Edward Elgar: Cheltenham, UK; Northampton, MA, USA, 2016; pp. 175-193.

119. Dopfer, K.; Potts, J. On the theory of economic evolution. Evol. Inst. Econ. Rev. 2009, 6, 23-44. [CrossRef]

120. Dopfer, K. The economic agent as rule maker and rule user: Homo Sapiens Oeconomicus. J. Evol. Econ. 2004, 14, 177-195. [CrossRef]

121. Dopfer, K.; Foster, J.; Potts, J. Micro-meso-macro. J. Evol. Econ. 2004, 14, 263-279. [CrossRef]

122. Blind, G.; Pyka, A. The rule approach in evolutionary economics: A methodological template for empirical research. J. Evol. Econ. 2014, 24, 1085-1105. [CrossRef]

123. Nelson, R.R.; Winter, S.G. An Evolutionary Theory of Economic Change; The Belknap Press of Harvard University Press: Cambridge, MA, USA, 1982.

124. Ostrom, E. Understanding Institutional Diversity; Princeton University Press: Princeton, NJ, USA, 2005.

125. Ostrom, E. The complexity of rules and how they may evolve over time. In Evolution and Design of Institutions; Schubert, C., von Wangenheim, G., Eds.; Routledge: London, UK; New York, NY, USA, 2006; pp. 100-122.

126. Ostrom, E.; Basurto, X. Crafting analytical tools to study institutional change. J. Inst. Econ. 2011, 7, 317-343. [CrossRef]

127. Meadows, D.H. Thinking in Systems: A Primer; Wright, D., Ed.; Earthscan: London, UK, 2008.

128. Capra, F.; Luisi, P.L. The Systems View of Life: A Unifying Vision; Cambridge University Press: Cambridge, UK, 2014.

129. Daimer, S.; Hufnagl, M.; Warnke, P. Challenge-oriented policy-making and innovation systems theory: Reconsidering systemic instruments. In Innovation System Revisited: Experiences from 40 Years of Fraunhofer ISI Research; Koschatzky, K., Ed.; Fraunhofer Verlag: Stuttgart, Germany, 2012; pp. 217-234.

130. Lindner, R.; Daimer, S.; Beckert, B.; Heyen, N.; Koehler, J.; Teufel, B.; Warnke, P.; Wydra, S. Addressing Directionality: Orientation Failure and the Systems of Innovation Heuristic. Towards Reflexive Governance. In Fraunhofer ISI Discussion Papers Innovation and Policy Analysis; Fraunhofer Institute for Systems and Innovation Research: Karlsruhe, Germany, 2016; Volume 52.

131. Almudi, I.; Fatas-Villafranca, F.; Potts, J. Utopia competition: A new approach to the micro-foundations of sustainability transitions. J. Bioecon. 2017, 19, 165-185. [CrossRef]

132. Miller, T.R.; Wiek, A.; Sarewitz, D.; Robinson, J.; Olsson, L.; Kriebel, D.; Loorbach, D. The future of sustainability science: A solutions-oriented research agenda. Sustain. Sci. 2014, 9, 239-246. [CrossRef]

133. Beddoe, R.; Costanza, R.; Farley, J.; Garza, E.; Kent, J.; Kubiszewski, I.; Martinez, L.; McCowen, T.; Murphy, K.; Myers, N.; et al. Overcoming systemic roadblocks to sustainability: The evolutionary redesign of worldviews, institutions, and technologies. Proc. Natl. Acad. Sci. USA 2009, 106, 2483-2489. [CrossRef] [PubMed]

134. Matutinović, I. Worldviews, institutions and sustainability: An introduction to a co-evolutionary perspective. Int. J. Sustain. Dev. World Ecol. 2007, 14, 92-102. [CrossRef]

135. Brewer, J.; Karafiath, L. Why Global Warming Won't Go Viral: A Research Report Prepared by DarwinSF 2013. Available online: https://www.slideshare.net/joebrewer31/why-global-warming-wont-go-viral (accessed on 14 April 2018).

136. Leach, M.; Stirling, A.; Scoones, I. Dynamic Sustainabilities: Technology, Environment, Social Justice; Earthscan: Abingdon, UK; New York, NY, USA, 2010.

137. Van Opstal, M.; Hugé, J. Knowledge for sustainable development: A worldviews perspective. Environ. Dev. Sustain. 2013, 15, 687-709. [CrossRef]

138. Breslin, D. Towards a generalized Darwinist view of sustainability. In Beyond Sustainability; Scholz, C., Zentes, J., Eds.; Nomos: Baden-Baden, Germany, 2014; pp. 13-35.

139. Zwier, J.; Blok, V.; Lemmens, P.; Geerts, R.-J. The ideal of a zero-waste humanity: Philosophical reflections on the demand for a bio-based economy. J. Agric. Environ. Ethics 2015, 28, 353-374. [CrossRef] 
140. Blok, V.; Gremmen, B.; Wesselink, R. Dealing with the wicked problem of sustainability in advance. Bus. Prof. Ethics J. 2016. [CrossRef]

141. Urmetzer, S.; Pyka, A. Varieties of knowledge-based bioeconomies. In Knowledge-Driven Developments in the Bioeconomy; Dabbert, S., Lewandowski, I., Weiss, J., Pyka, A., Eds.; Springer: Cham, Switzerland, 2017; pp. 57-82.

142. Hodgson, G.M. The evolution of morality and the end of economic man. J. Evol. Econ. 2014, 24, 83-106. [CrossRef]

143. Wuketits, F.M. Moral systems as evolutionary systems: Taking evolutionary ethics seriously. J. Soc. Evol. Syst. 1993, 16, 251-271. [CrossRef]

144. Boyd, R.; Richerson, P.J. Culture and the Evolutionary Process; University of Chicago Press: Chicago, IL, USA, 1985.

145. Boyd, R.; Richerson, P.J. The evolution of norms: An anthropological view. J. Inst. Theor. Econ. 1994, 150, 72-87.

146. Boyd, R.; Richerson, P.J. The Origin and Evolution of Cultures; Oxford University Press: Oxford, UK; New York, NY, USA, 2005.

147. Richerson, P.J.; Boyd, R. Not by Genes Alone: How Culture Transformed Human Evolution; University of Chicago Press: Chicago, IL, USA, 2005.

148. Ayala, F.J. The biological roots of morality. Biol. Philos. 1987, 2, 235-252. [CrossRef]

149. Waring, T.M.; Kline, M.A.; Brooks, J.S.; Goff, S.H.; Gowdy, J.; Janssen, M.A.; Smaldino, P.E.; Jacquet, J. A multilevel evolutionary framework for sustainability analysis. EES 2015, 20. [CrossRef]

150. Markey-Towler, B. The competition and evolution of ideas in the public sphere: A new foundation for institutional theory. J. Inst. Econ. 2018, 43, 1-22. [CrossRef]

151. Almudi, I.; Fatas-Villafranca, F.; Izquierdo, L.R.; Potts, J. The economics of utopia: A co-evolutionary model of ideas, citizenship and socio-political change. J. Evol. Econ. 2017, 27, 629-662. [CrossRef]

152. Johnson, B. Institutional learning. In National Systems of Innovation: Toward a Theory of Innovation and Interactive Learning; Lundvall, B.-Å., Ed.; Anthem Press: London, UK, 2010; pp. $23-45$.

153. Göpel, M. The Great Mindshift; Springer International Publishing: Cham, Switzerland, 2016.

154. Schaper-Rinkel, P. Bio-politische Ökonomie: Zur Zukunft des Regierens von Biotechnologien. In Bioökonomie: Die Lebenswissenschaften und die Bewirtschaftung der Körper; Lettow, S., Ed.; Transcript: Bielefeld, Germany, 2012; pp. 155-179.

155. Banks, J.A. The canon debate, knowledge construction, and multicultural education. Educ. Res. 1993, 22, 4-14. [CrossRef]

156. Sterling, S. Transformative learning and sustainability: Sketching the conceptual ground. Learn. Teach. High. Educ. 2011, 17-33.

157. Mezirow, J. Transformative Dimensions of Adult Learning; Jossey-Bass: San Francisco, CA, USA, 1991.

158. Dirkx, J.M. Transformative learning theory in the practice of adult education: An overview. PAACE J. Lifelong Learn. 1998, 7, 1-14.

159. Focus. Kretschmann kauft sich neues Dieselauto-Fahrverbote für alte Diesel bleiben. Focus. 21 May 2017. Available online: https://www.focus.de/auto/news/abgas-skandal/mache-was-ich-fuer-richtig-haltegruener-ministerpraesidentin-kauft-sich-neues-dieselauto-fahrverbote-fuer-alte-diesel-bleiben_id_ 7160275.html (accessed on 7 April 2018).

160. Brewer, J. Tools for culture design: Toward a science of social change? Spanda J. 2015, 6, 67-73.

161. Wilson, D.S. Intentional cultural change. Curr. Opin. Psychol. 2016, 8, 190-193. [CrossRef] [PubMed]

162. Wilson, D.S.; Hayes, S.C.; Biglan, A.; Embry, D.D. Evolving the future: Toward a science of intentional change. Behav. Brain Sci. 2014, 37, 395-416. [CrossRef] [PubMed]

163. Biglan, A.; Barnes-Holmes, Y. Acting in light of the future: How do future-oriented cultural practices evolve and how can we accelerate their evolution? J. Context. Behav. Sci. 2015, 4, 184-195. [CrossRef] [PubMed]

164. Ramcilovic-Suominen, S.; Pülzl, H. Sustainable development-A 'selling point' of the emerging EU bioeconomy policy framework? J. Clean. Prod. 2018, 172, 4170-4180. [CrossRef]

165. Schmid, O.; Padel, S.; Levidov, L. The bio-economy concept and knowledge base in a public goods and farmer perspective. Bio-Based Appl. Econ. 2012, 1, 47-63.

166. Hilgartner, S. Making the bioeconomy measurable: Politics of an emerging anticipatory machinery. BioSocieties 2007, 2, 382-386. [CrossRef] 
167. Birch, K.; Levidow, L.; Papaioannou, T. Sustainable capital? The neoliberalization of nature and knowledge in the European "knowledge-based bio-economy". Sustainability 2010, 2, 2898-2918. [CrossRef]

168. McCormick, K.; Kautto, N. The bioeconomy in Europe: An overview. Sustainability 2013, 5, $2589-2608$. [CrossRef]

169. Fatheuer, T.; Fuhr, L.; Unmüßig, B. Kritik der Grünen Ökonomie; Oekom Verlag: München, Germany, 2015.

170. Albrecht, S.; Gottschick, M.; Schorling, M.; Stirn, S. Bio-Ökonomie-Gesellschaftliche Transformation ohne Verständigung über Ziele und Wege? Biogum Univ: Hamburg, Germany, 2012.

171. Raghu, S.; Spencer, J.L.; Davis, A.S.; Wiedenmann, R.N. Ecological considerations in the sustainable development of terrestrial biofuel crops. Curr. Opin. Environ. Sustain. 2011, 3, 15-23. [CrossRef]

172. ten Bos, R.; van Dam, J.E.G. Sustainability, polysaccharide science, and bio-economy. Carbohydr. Polym. 2013, 93, 3-8. [CrossRef] [PubMed]

173. Schütte, G. What kind of innovation policy does the bioeconomy need? New Biotechnol. 2018, 40, 82-86. [CrossRef] [PubMed]

174. European Commission. Innovating for Sustainable Growth: A Bioeconomy for Europe; European Commission: Brussels, Belgium, 2012.

175. European Commission. Review of the 2012 European Bioeconomy Strategy; European Commission: Brussels, Belgium, 2017.

176. The European Bioeconomy Stakeholders Panel. European Bioeconomy Stakeholders Manifesto. Available online: https:/ / ec.europa.eu/research/bioeconomy/pdf/european_bioeconomy_stakeholders_ manifesto.pdf (accessed on 16 April 2018).

177. Meyer, M. The rise of the knowledge broker. Sci. Commun. 2010, 32, 118-127. [CrossRef]

178. Castells, M. The Rise of the Network Society, 2nd ed.; Wiley-Blackwell: Chichester, UK, 2010.

179. Castells, M. The Power of Identity, 2nd ed.; Wiley-Blackwell: Chichester, UK, 2010.

180. Castells, M. End of Millennium, 2nd ed.; Wiley-Blackwell: Chichester, UK, 2010.

181. Copagnon, D.; Chan, S.; Mert, A. The changing role of the state. In Global Environmental Governance Reconsidered; Biermann, F., Pattberg, P., Eds.; MIT Press: Cambridge, MA, USA, 2012; pp. 237-264.

182. Wyborn, C.A. Connecting knowledge with action through coproductive capacities: Adaptive governance and connectivity conservation. EES 2015, 20. [CrossRef]

183. Folke, C.; Hahn, T.; Olsson, P.; Norberg, J. Adaptive governance of social-ecological systems. Annu. Rev. Environ. Resour. 2005, 30, 441-473. [CrossRef]

184. Boyd, E.; Folke, C. (Eds.) Adapting Institutions: Governance, Complexity and Social-Ecological Resilience; Cambridge University Press: Cambridge, UK, 2012.

185. Voß, J.-P.; Bauknecht, D.; Kemp, R. (Eds.) Reflexive Governance for Sustainable Development; Edward Elgar: Cheltenham, UK, 2006.

186. Biermann, F. Earth System Governance: World Politics in the Anthropocene; The MIT Press: Cambridge, MA, USA, 2014.

187. von Schomberg, R. A vision of responsible research and innovation. In Responsible Innovation: Managing the Responsible Emergence of Science and Innovation in Society; Owen, R., Bessant, J.R., Heintz, M., Eds.; John Wiley \& Sons Inc.: Chichester, UK, 2013; pp. 51-74.

188. Scoones, I.; Leach, M.; Newell, P. (Eds.) The Politics of Green Transformations; Earthscan: London, UK, 2015.

189. Milkoreit, M. Mindmade Politics: The Cognitive Roots of International Climate Governance; The MIT Press: Cambridge, MA, USA, 2017.

190. Bugge, M.M.; Coenen, L.; Branstad, A. Governing socio-technical change: Orchestrating demand for assisted living in ageing societies. Sci. Public Policy 2018, 38, 1235. [CrossRef]

191. Evans, J.; Jones, R.; Karvonen, A.; Millard, L.; Wendler, J. Living labs and co-production: University campuses as platforms for sustainability science. Curr. Opin. Environ. Sustain. 2015, 16, 1-6. [CrossRef]

192. Frantzeskaki, N.; Kabisch, N. Designing a knowledge co-production operating space for urban environmental governance-Lessons from Rotterdam, Netherlands and Berlin, Germany. Environ. Sci. Policy 2016, 62, 90-98. [CrossRef]

193. Kahane, A. Transformative Scenario Planning: Working Together to Change the Future; Berrett-Koehler Publishers: San Francisco, CA, USA, 2012. 
194. Luederitz, C.; Schäpke, N.; Wiek, A.; Lang, D.J.; Bergmann, M.; Bos, J.J.; Burch, S.; Davies, A.; Evans, J.; König, A.; et al. Learning through evaluation-A tentative evaluative scheme for sustainability transition experiments. J. Clean. Prod. 2017, 169, 61-76. [CrossRef]

195. Mauser, W.; Klepper, G.; Rice, M.; Schmalzbauer, B.S.; Hackmann, H.; Leemans, R.; Moore, H. Transdisciplinary global change research: The co-creation of knowledge for sustainability. Curr. Opin. Environ. Sustain. 2013, 5, 420-431. [CrossRef]

196. Moser, S.C. Can science on transformation transform science? Lessons from co-design. Curr. Opin. Environ. Sustain. 2016, 20, 106-115. [CrossRef]

197. Wiek, A. Challenges of transdisciplinary research as interactive knowledge generation: Experiences from transdisciplinary case study research. GAIA 2007, 16, 52-57. [CrossRef]

198. Wiek, A.; Ness, B.; Schweizer-Ries, P.; Brand, F.S.; Farioli, F. From complex systems analysis to transformational change: A comparative appraisal of sustainability science projects. Sustain. Sci. 2012, 7, 5-24. [CrossRef]

199. Albrecht, S.; Gottschick, M.; Schorling, M.; Stirn, S. Bioökonomie am Scheideweg: Industrialisierung von Biomasse oder nachhaltige Produktion? GAIA 2012, 21, 33-37. [CrossRef]

200. Costanza, R. How do cultures evolve, and can we direct that change to create a better world? Wildl. Aust. 2016, 53, 46-47.

201. Mesoudi, A. Cultural evolution: Integrating psychology, evolution and culture. Curr. Opin. Psychol. 2016, 7, 17-22. [CrossRef]

202. Mesoudi, A. Cultural evolution: A review of theory, findings and controversies. Evol. Biol. 2016, 43, 481-497. [CrossRef]

203. Mesoudi, A. Pursuing Darwin's curious parallel: Prospects for a science of cultural evolution. Proc. Natl. Acad. Sci. USA 2017. [CrossRef] [PubMed]

204. Voß, J.-P.; Kemp, R. Sustainability and reflexive governance: Introduction. In Reflexive Governance for Sustainable Development; Voß, J.-P., Bauknecht, D., Kemp, R., Eds.; Edward Elgar: Cheltenham, UK, 2006; pp. 3-28.

205. Fagerberg, J. Mission (Im)possible? The Role of Innovation (and Innovation Policy) in Supporting Structural Change \& Sustainability Transitions; Centre for Technology, Innovation and Culture, University of Oslo, Oslo, Norway, 2017. Available online: https:/ / www.sv.uio.no/tik/InnoWP/tik_working_paper_20180216.pdf (accessed on 16 April 2018).

206. Bioökonomierat. Empfehlungen des Bioökonomierates: Weiterentwicklung der "Nationalen Forschungsstrategie Bioökonomie 2030"; Bioökonomierat: Berlin, Germany, 2016.

207. BMEL. Fortschrittsbericht zur Nationalen Politikstrategie Bioökonomie; Bundesministerium für Ernährung und Landwirtschaft: Berlin, Germany, 2016.

208. Imbert, E.; Ladu, L.; Morone, P.; Quitzow, R. Comparing policy strategies for a transition to a bioeconomy in Europe: The case of Italy and Germany. Energy Res. Soc. Sci. 2017, 33, 70-81. [CrossRef]

209. Abson, D.J.; Fischer, J.; Leventon, J.; Newig, J.; Schomerus, T.; Vilsmaier, U.; von Wehrden, H.; Abernethy, P.; Ives, C.D.; Jager, N.W.; et al. Leverage points for sustainability transformation. Ambio 2017, 46, 30-39. [CrossRef] [PubMed]

(C) 2018 by the authors. Licensee MDPI, Basel, Switzerland. This article is an open access article distributed under the terms and conditions of the Creative Commons Attribution (CC BY) license (http://creativecommons.org/licenses/by/4.0/). 